\title{
ReSEARChArticle
}

\section{Jatropha cultivation: A strategy for biodiesel production in India}

\author{
SUKANTA SARKAR
}

\section{SUMMARY}

Jatropha grows in tropical and sub tropical regions. Jatropha oil is a possible feedstock for biodiesel production. Oil extraction can be done either mechanically or chemically. The oil can be used for lighting purposes. Soap production on a jatropha oil basis is possible with only two additional ingredients: lye and carbonate. Besides energy security and environmental benefits, jatropha offers a potential opportunity to address the issues of rural livelihoods and poverty. The objective of this paper was to study the importance of Jatropha tree for biofuel in $21^{\text {st }}$ centuary.

Key Words : Jatropha cultivation, Biodiesel, Fuel, Oilseed, Small farmers

How to cite this article : Sarkar, Sukanta (2017). Jatropha cultivation: A strategy for biodiesel production in India. Internat. J. Plant Sci., 12 (2): 181-183, DOI: 10.15740/HAS/IJPS/12.2/181-183.

Article chronicle : Received : 23.01.2017; Revised : 13.05.2017; Accepted : 01.06.2017 